\title{
Nitrogen Use Efficiency under Different Field Treatments on Maize Fields in Central China: A Lysimeter and ${ }^{15} \mathrm{~N}$ Study
}

\author{
Jin Zhang ${ }^{12^{*}}$, Zhao-Hua $\mathrm{Li}^{3}$, Kun $\mathrm{Li}^{3}$, Wei Huang ${ }^{1}$, Lian-Hai Sang ${ }^{1}$ \\ ${ }^{1}$ Center for Development Research (ZEF), University of Bonn, Bonn, Germany \\ ${ }^{2}$ Yangtze River Scientific Research Institute, Wuhan, China \\ ${ }^{3}$ Faculty of Resource and Environment, Hubei University, Wuhan, China \\ Email: "zhangjin@uni-bonn.de
}

Received May 7, 2012; revised June 17, 2012; accepted June 23, 2012

\begin{abstract}
Nitrogen loss from farmland has caused serious problems all over the world. This field study assessed Nitrogen Use Efficiency $^{1}$ (NUE) and biomass yield under four different field treatments in the Hubei Province, in central China. Results show that 1) in these four treatments, the maize monoculture plots have the highest rate of fertilizer $\mathrm{N}$ losses (69.12\%), and the lowest (32.45\%) is treated by surface rice straw mulch of maize intercrop with peanut; 2) compared with monoculture, polyculture plots have $36.9 \mathrm{~kg} \cdot \mathrm{ha}^{-1}$ and $26.57 \mathrm{~kg} \cdot \mathrm{ha}^{-1}$ more nitrogen absorption in the mulched and un-mulched plots respectively, however, polyculture has a lesser effect on NUE; 3) surface straw mulch is an effective way to keep nitrogen in the soil $(0-100 \mathrm{~cm})$, however it may decrease dry matter yield in monoculture plots; 4) maize intercrop with peanut and surface mulch can keep $47.63 \%$ of the fertilizer $\mathrm{N}$ in the soil profiles $(0-100 \mathrm{~cm})$, which is the highest among these four treatments.
\end{abstract}

Keywords: Monoculture; Surface Mulch; Nitrogen Use Efficiency; Leaching; Biomass Yield

\section{Introduction}

Nitrogen is one of the essential elements for plant growth, as it is not only promotes plant growth but also acts as a building block for protein. In order to increase yield, fertilizer consumption has continued to increase across the world since the $19^{\text {th }}$ century. The global production of fertilizer has increased from 27.4 million tons in 1960 to 143.6 million tons in 1990, and it will rise further to 208 million tons in 2020 [1]. Because of low NUE, the more fertilizer $\mathrm{N}$ applied, the more nitrogen was lost. Only $30 \%-35 \%$ of the fertilizer $\mathrm{N}$ was taken up by plants and about 20\% - 50\% went away through leaching and runoff [2-4]. Nitrogen lost from farmland is the main source of non-point source pollution for water systems, causing problems of groundwater nitrate pollution, surface water eutrophication, and natural ecological degradation.

Researches into nitrogen losses from agricultural activities commenced several decades ago, founding a consensus that nitrogen losses from agricultural land is the main source of water $\mathrm{NO}_{3}^{-}$contamination around the globe [5]. Nitrogen loss reduction strategies such as manure fertilizer [6,7], fertilizer application methods [8], en-

\footnotetext{
*Corresponding author.

${ }^{1}$ Nitrogen Use Efficiency in this research is defined as the part of the applied fertilizer nitrogen which is found in the plant.
}

vironmental policies [9,10], surface mulching [11], tillage/irrigation skills [12,13] (Meek, et al., 1995; Turpin, et al., 1998) and proper intercropping system [14] have been well documented in existing researches. However, most of the studies were focused on nitrogen losses or NUE, with less research being conducted on nitrogen losses reduction with the yield consideration [15]. Nitrogen pollution mitigation strategies without yield consideration cannot be implemented in China, because most farmers small-scale and therefore pursue high yields to support their families.

In this paper, we used on-site lysimeters and a stable isotope ${ }^{15} \mathrm{~N}$ urea to compare the nitrogen distribution, NUE and biomass yield of four different field treatments in central China. We first analyzed nitrogen distribution and yield under different treatments, and then examined the ${ }^{15} \mathrm{~N}$ rate in the soil and crops to determine NUE. Finally, we discussed the field treatments which may improve NUE and reduce nitrogen losses without sacrificing the yield.

\section{Materials and Methods}

\subsection{Site Description}

Lysimeters and a ${ }^{15} \mathrm{~N}$ enriched urea were used in this 
experiment, established in Zhijiang City, in the western part of Hubei Province (central China) (N43.715635, E87.251374). The region has a moist monsoon climate with a mean annual temperature of $16.5^{\circ} \mathrm{C}$, and a mean annual rainfall of $1032.7 \mathrm{~mm}$. The soil in the experiment field is yellow-brown, and the properties of the surface soil $(0-20 \mathrm{~cm})$ are listed in Table 1.

\subsection{Treatments}

The experiment was a split-plot factorial design with two factors and three replicates. Three lysimeters are located in each of the plots, (with the plots being $5 \mathrm{~m}$ wide $* 8 \mathrm{~m}$ long), and the lysimeter is $1.5 \mathrm{~m}$ wide $* 1.5 \mathrm{~m}$ long $* 1.3$ $\mathrm{m}$ deep, leaving an edge of $0.3 \mathrm{~m}$ lysimeter above the soil surface when put into the field. The four treatments are: (1) maize monoculture (C); (2) maize intercrop with peanut $(\mathrm{C}+\mathrm{P})$; (3) maize with rice straw mulch $(\mathrm{C}+\mathrm{M})$; (4) maize intercrop with peanut and rice straw mulch $(\mathrm{C}+\mathrm{P}$ $+\mathrm{M})$. There are two rows of peanut between two rows of maize. In the monoculture plots, the plant density is 36,000 maize $\cdot \mathrm{ha}^{-1}$; in the polyculture plots, the plant density is 17000 maize $\cdot$ ha $^{-1}$ and 180000 peanuts $\cdot$ ha $^{-1}$. Only urea is applied to the maize, and no nitrogen fertilizer is applied to peanut. $276 \mathrm{~kg} \mathrm{~N} \cdot \mathrm{ha}^{-1}, 252 \mathrm{Kg} \mathrm{K} \cdot \mathrm{ha}^{-1}$ and 126 $\mathrm{kg} \mathrm{P} \cdot \mathrm{ha}^{-1}$ were applied in the monoculture plots; $130 \mathrm{Kg}$ $\mathrm{N} \cdot \mathrm{ha}^{-1}, 252 \mathrm{Kg} \mathrm{K} \cdot \mathrm{ha}^{-1}$ and $126 \mathrm{~kg} \mathrm{P} \cdot \mathrm{ha}^{-1}$ were applied in the polyculture plots. According to the farmers' conventional methods, the urea were applied twice, with $111 \mathrm{Kg}$ $\mathrm{N} \cdot \mathrm{ha}^{-1}$ (monoculture) and $52 \mathrm{Kg} \mathrm{N} \cdot \mathrm{ha}^{-1}$ (polyculture) at planting as a basic fertilizer, and with $165 \mathrm{Kg} \mathrm{N} \cdot \mathrm{ha}^{-1}$ (monoculture) and $78 \mathrm{Kg} \mathrm{N} \cdot \mathrm{ha}^{-1}$ (polyculture) as a topdressing when the maize plants reach the stage of two fully expanded leaves. All of the potassium and phosphorous was applied at once in the first time. The basic fertilizer was applied on 5 May, 2008, at the same time of transplant maize and sowing peanuts; and the topdress was applied on 31 May, 2008. All of the crops in the lysimeter received ${ }^{15} \mathrm{~N}$ enriched urea, and ordinary $\mathrm{P}$ and $\mathrm{K}$ fertilizers. The abundance of the ${ }^{15} \mathrm{~N}$ urea is $5.02 \%$.

\subsection{Sample Collection and Lab Analysis}

In order to determine the nitrogen assimilated by the crops, all of the crops were harvested including roots (0 $20 \mathrm{~cm}$ ). Crop samples were separated to grain and stem. Subsequently, all of the samples were dried at $70^{\circ} \mathrm{C}$ until constant weight, and then crushed to powder until pass- ing a $0.15 \mathrm{~mm}$ sieve, waiting for Total Nitrogen Concentration (TNC) and ${ }^{15} \mathrm{~N}$ abundance analysis.

The drainage water sample of each lysimeter was collected whenever drainage occured, stored with dark glass bottles in the refrigerator at $4^{\circ} \mathrm{C}$, and then returned to the laboratory for TNC analysis. Unfortunately, ${ }^{15} \mathrm{~N}$ abundance in leached water hadn't been analyzed; therefore, fertilizer $\mathrm{N}$ deficit in this research includes gaseous and water losses.

After the crops were harvested in August, soil samples in each plot were collected from a depth of 0 - 20, 20 - 40, $40-60,60-80$ and $80-100 \mathrm{~cm}$. The mass of TNC and fertilizer utilization was calculated after considering the bulk density of different soil layers.

\subsection{Methodology in Lab}

1) Water samples: filtered and sent to the lab for TNC analysis on an Alpkem Flow Solution IV auto-analyzer.

2) Plant tissues: TNC in grain and stem of the subsamples were determined by the micro-Kjeldahl method by digesting the sample in $\mathrm{H}_{2} \mathrm{SO}_{4}-\mathrm{H}_{2} \mathrm{O}_{2}$ solution. The crop samples that waited for ${ }^{15} \mathrm{~N}$ were solute as the TNC method, and the solute samples were analyzed by using isotope mass spectrometer detector (ANCA-SL/20-20).

3) Soil samples: $10 \mathrm{~g}$ of the sub-samples were placed in a $100 \mathrm{ml} 2 \mathrm{~N} \mathrm{KCl}$, shaken for $1 \mathrm{~min}$ and allowed to equilibrate for 18-24 hrs. Supernatant was removed and stored at $4^{\circ} \mathrm{C}$. The TNC in the supernatant was measured colorimetrically on the Lachate auto-analysis system. The ${ }^{15} \mathrm{~N}$ in the supernatant was determined by an isotope mass spectrometer detector (ANCA-SL/20-20).

\section{Results and Discussion}

\subsection{Nitrogen in the Soil}

TNC in the soil layers were varied among different treatments. Figure 1 shows that in terms of the TNC change trend in the soil of $0-100 \mathrm{~cm}$, there were steady decreases in the two plots which were treated by monoculture; however, it decreased slowly in the two plots treated by polyculture, especially in the plot of $\mathrm{C}+\mathrm{P}+$ $M$ which increased in the layer of $0-60 \mathrm{~cm}$ and then decreased sharply. The highest TNC in the surface layer $(0$ - $20 \mathrm{~cm}$ ) is the plot of $\mathrm{C}+\mathrm{M}$ which reached up to 1514 $\mathrm{kg} / \mathrm{ha}$, the other three plots were approximately in the range of $900 \mathrm{~kg} \cdot \mathrm{ha}^{-1}$.

Straw mulch cannot only keep nitrogen in the surface

Table 1. Soil properties before experiment.

\begin{tabular}{|c|c|c|c|c|c|c|c|c|}
\hline $\mathrm{pH}$ & $\begin{array}{l}\text { Organic Matter } \\
\qquad\left(\mathrm{g} \cdot \mathrm{Kg}^{-1}\right)\end{array}$ & $\begin{array}{c}\text { CEC } \\
\left(\mathrm{mmol}^{\prime} \mathrm{kg}^{-1}\right)\end{array}$ & $\begin{array}{c}\text { Available } \\
\mathrm{N}\left(\mathrm{mg} \cdot \mathrm{Kg}^{-1}\right)\end{array}$ & $\begin{array}{l}\text { Extractable } \\
\mathrm{P}\left(\mathrm{mg} \cdot \mathrm{Kg}^{-1}\right)\end{array}$ & $\begin{array}{l}\text { Exchangeable } \\
\mathrm{K}\left(\mathrm{mg} \cdot \mathrm{Kg}^{-1}\right)\end{array}$ & $\begin{array}{c}\text { Total } \\
\mathrm{N}\left(\mathrm{g} \cdot \mathrm{Kg}^{-1}\right)\end{array}$ & $\begin{array}{c}\text { Total } \\
\mathrm{P}\left(\mathrm{g} \cdot \mathrm{Kg}^{-1}\right)\end{array}$ & $\begin{array}{c}\text { Total } \\
\mathrm{K}\left(\mathrm{g} \cdot \mathrm{Kg}^{-1}\right)\end{array}$ \\
\hline 6.27 & 9.49 & 10.2 & 9.67 & 3.0 & 72.3 & 0.21 & 0.16 & 8.65 \\
\hline
\end{tabular}




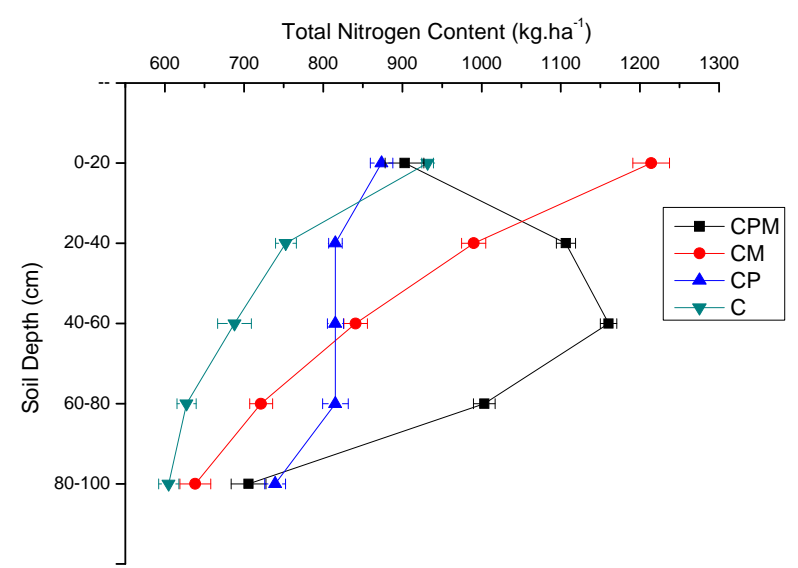

Figure 1. Total nitrogen retention in the soil $(0-100 \mathrm{~cm})$ after harvest.

layer of the soil, but also can improve the yield and water use efficiency [16]. Alexandra found that a mulch-based cropping system could increase TNC in the surface soil layer $(0-30 \mathrm{~cm})$ in the long-term. Similar results were found in this experiment, with the TNC of the surface soil layer $(0-60 \mathrm{~cm})$ in the mulched plots being higher than the un-mulched ones. However, there were no significant differences in the deeper soil layer $(80-100 \mathrm{~cm})$ among these four treatments. Conversely, the plots treated by $\mathrm{C}+\mathrm{M}$ had higher TNC in the soil layer of $0-20$ $\mathrm{cm}$. This may be due to the straw being decomposed 3 months after mulching; however, maize cannot utilize surface nitrogen because of its deeper root and less rainfall at that time.

In summary, mulch and polyculture are the two treatments keeping nitrogen in the surface soil layer $(0$ - 60 $\mathrm{cm}$ ) which provide more nutrients for the crops of next season. However, nitrogen accumulation in the soil is regarded as a potential danger for the water system, because it is leached out when the rainy season arrives. Its termed as a "memory effect" in [17]. Therefore, C + P + $\mathrm{M}$ is suitable for intensive agriculture, because it can provide more nutrients for the following season with less fertilizer $\mathrm{N}$ consumption.

\subsection{Nitrogen in the Leachate}

With regards to TNC in the leachate, there were no obvious differences between the four treatments, Figure 2. After basic fertilizer was applied, there was no drainage water in the lysimeter until 6 June. At beginning, the TNC in the leachate from the two plots treated by mulch were a little lower than the other two plots.

During the whole cropping period, the peak of the TNC in the leachate occurred three months after the basic fertilizer was applied, and reached up to more than 7 $\mathrm{kg} \cdot \mathrm{ha}^{-1}$.

There are two reasons which might explain this phe- nomenon. Firstly, plants do not consume too much nitrogen after the growing period, therefore the nitrogen in the root zone will be leached. Secondly, as [18] described, the period which is most prone to leaching is autumn, because during that time evaporation decreases and soil moisture increases, soil microbial activities increase, and there is an increased mineralization of organic nitrogen, which cause more nitrogen to be leached.

Two months after the basic fertilizer was applied (30 June), the TNC in the leachate was at the bottom. We consider this to be because two months after maize being planted is the fast growing period, with nitrogen being rapidly taken up by the crops, and the amount of the fertilizer nitrogen leached during this season is normally low [19].

\subsection{Biomass Yield and Nitrogen Absorption}

The crops' nitrogen absorption in the plots which were treated by polyculture was much higher than in the monoculture plots. The highest nitrogen absorption by the crops was the treatment of $\mathrm{C}+\mathrm{P}+\mathrm{M}$, reaching up to $124 \mathrm{~kg} / \mathrm{ha}$; the lowest was $\mathrm{C}+\mathrm{M}$, which only recorded $87.6 \mathrm{~kg} / \mathrm{ha}$. As for monoculture, un-mulched plots had higher nitrogen absorption than mulched plots, which is similar to the results of other research (Wang Wei-Ming, 1986). The main reason is that straw has a high C/N content which may cause nitrogen immobilization. Therefore available nitrogen in the plots of $\mathrm{C}+\mathrm{M}$ is not sufficient for the crops' growth. However, the intercropping plots had the opposite results; with the reason being that the nitrogen fixed by the peanut is not Figure 3 shows that the crops' nitrogen absorption in the plots which were treated by polyculture were much higher than in the monoculture plots. The highest nitrogen absorption by the crops was the treatment of $\mathrm{C}+\mathrm{P}+\mathrm{M}$, reaching up to

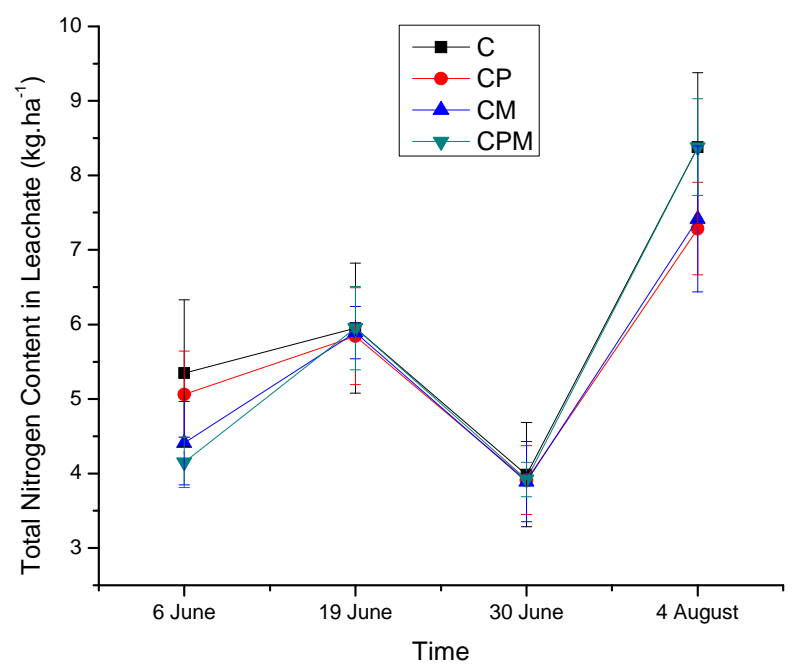

Figure 2. Nitrogen leaching from farmland during grow season. 


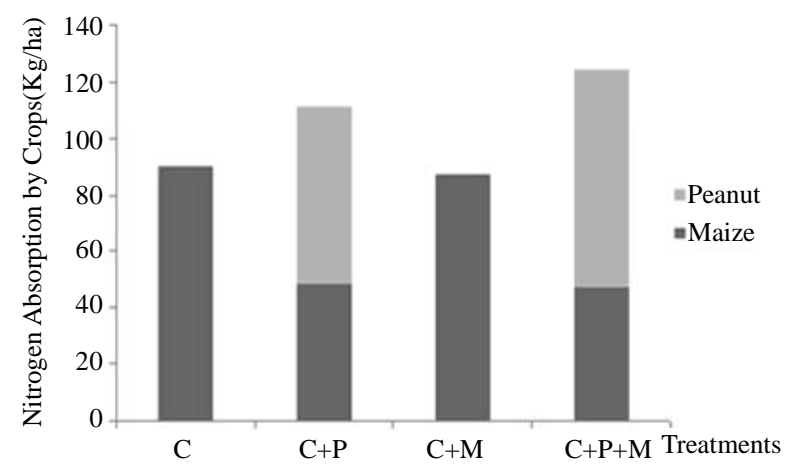

Figure 3. Nitrogen absorption by crops after harvest.

$124 \mathrm{~kg} / \mathrm{ha}$; the lowest was $\mathrm{C}+\mathrm{M}$, which only recorded $87.6 \mathrm{~kg} / \mathrm{ha}$. As for monoculture, un-mulched plots had a higher nitrogen absorption than mulched plots, which is similar to the results of other research (Wang Wei-Ming, 1986). The main reason is that straw has a high $\mathrm{C} / \mathrm{N}$ content which may cause nitrogen immobilization, therefore available nitrogen in the plots of $\mathrm{C}+\mathrm{M}$ is not sufficient for the crops' growth. However, the intercropping plots had the opposite results; with the reason being that the nitrogen fixed by the peanut is not only used by the crops but also by the microorganism. Therefore the number of microorganisms in the soil explodes in a short time, and the microorganism can decompose the mulched straw which will provide more nitrogen resources for the crops that may contribute to the yield enhancement by intercropping [20].

Compared to monoculture, the intercropping system contributes greatly to crop production through its effective utilization of resources [21,22]. This research produced the same results, with crops absorbing more nitrogen in plots which were treated by polyculture. This is because legumes can fix nitrogen from the air and pass it to the cereals which are intercropped with them [23-25]. However, if it is not handled properly, polyculture will fail to work better than monoculture. For example, when maize is intercropped with ryegrass, they not only showed weaker growth but also took up smaller amounts of nitrogen than plant maize alone [26].

\section{Nitrogen Recovery}

Fertilizer $\mathrm{N}$ utilization by crops and retention in the soil were calculated as Equations (1)-(6):

$$
\begin{aligned}
& \begin{array}{l}
\% \text { utilization of added fertiliser }=\frac{\text { Amount of n }}{\text { Amo }} \\
\% \text { Ndff }=\frac{\text { atom } \%{ }^{15} \mathrm{~N} \text { excess }}{(\text { plant/soil/water) }} \\
\text { atom } \%{ }^{15} \mathrm{~N} \text { excess } \\
(\text { Fertilizer })
\end{array} \\
& \mathrm{DM} \text { yield }(\mathrm{kg} / \mathrm{ha})=\mathrm{FW}(\mathrm{kg}) \times \frac{10000\left(\mathrm{~m}^{2} / \mathrm{ha}\right)}{\text { area harvested }\left(\mathrm{m}^{2}\right)} \times \frac{\mathrm{SDW}(\mathrm{kg})}{\mathrm{SFW}(\mathrm{kg})} \\
& \mathrm{N} \text { yield }(\mathrm{kg} / \mathrm{ha})=\mathrm{DM} \text { yield }(\mathrm{kg} / \mathrm{ha}) \times \frac{\% \mathrm{~N}}{100} \\
& \text { Fertilizer } \mathrm{N} \text { yield }(\mathrm{kg} / \mathrm{ha})=\mathrm{N} \text { yield }(\mathrm{kg} / \mathrm{ha}) \times \frac{\% \mathrm{Ndff}}{100} \\
& \% \text { fertilizer } \mathrm{N} \text { utilization }=\frac{\text { Fertilizer } \mathrm{N} \text { yield }}{\text { Rate of } \mathrm{N} \text { application }} \times 100
\end{aligned}
$$

where:

Ndff-Fraction of $\mathrm{N}$ in the plant derived from the ${ }^{15} \mathrm{~N}$ labeled fertilizer.

FW-Fresh weight per area harvested.

SDW-Subsample dry weight.

SFW-Subsample fresh weight.

DM-Dry matter Yield.

\subsection{Fertilizer $N$ Utilized by Crops}

Considering fertilizer $\mathrm{N}$ utilization by crops, $\mathrm{C}+\mathrm{P}$ had the highest NUE (reaching up to 24.38\%), while maize monoculture had the lowest NUE of only $18.36 \%$. Because competition exists between the two crops which are planted together, the intercropping system has efficiency more efficient use of natural resources [27-29].

In the two plots which were treated by monoculture, straw mulch increased the NUE, however the plots treated by polyculture displayed the opposite trend. In the polyculture plots, mulched plots had a higher nitrogen absorption yet lower NUE. This may be because peanuts 
can fix the nitrogen, therefore the system has enough nitrogen resources, and mulched straw can be decomposed fast and provides more nitrogen resources for the crops (which can cause lower NUE). In the monoculture plots, surface mulch can reduce the fertilizer nitrogen percolation and volatilization, which may improve NUE; therefore, mulched crops have higher NUE.

\subsection{Fertilizer $\mathbf{N}$ Retention in the Soil}

When maize is intercropped with legume crops, nitrogen content in the soil profiles will improve significantly [30]. In our experiment, $47.63 \%$ of the fertilizer $\mathrm{N}$ remained in the soil $(0-100 \mathrm{~cm})$ after harvest in the plots of $\mathrm{C}+\mathrm{P}+$ $\mathrm{M}$, which was the highest amongst these four treatments. However, maize monoculture plots have the lowest fertilizer $\mathrm{N}$ soil retention (only $12.52 \%$ ). This is because legume crops can improve soil fertility through biological nitrogen $(\mathrm{N})$ fixation [31].

Straw mulch can increase the soil fertilizer $\mathrm{N}$ retention, $\mathrm{NO}_{3}^{-}$content and improve soil fertility after harvest [32]. Results show that the fertilizer $\mathrm{N}$ soil retention in the polyculture plots which were treated by mulch and unmulch were $47.634 \%$ and $30.69 \%$ respectively; in the monoculture plots, the figures were $23.06 \%$ and $12.52 \%$ respectively.

Table 2. Dry matter yield and nitrogen absorption by crops under different field treatments.

\begin{tabular}{|c|c|c|c|c|c|c|}
\hline \multirow{2}{*}{ Treatments } & \multicolumn{3}{|c|}{ Fertilization (kg/ha) } & \multicolumn{2}{|c|}{ Dry Matter (kg/ha) } & \multirow{2}{*}{ Nitrogen Absorption (kg N/ha) } \\
\hline & $\mathrm{N}$ & $\mathrm{P}$ & $\mathrm{K}$ & Biomass & Grain & \\
\hline \multicolumn{7}{|l|}{$\mathrm{C}$} \\
\hline Maize & 276 & 126 & 252 & $16253.3 \pm 150.3$ & $6540 \pm 62.3$ & $90.3 \pm 7.5$ \\
\hline \multicolumn{7}{|l|}{$\mathrm{C}+\mathrm{P}$} \\
\hline Maize & 130 & \multirow{2}{*}{126} & \multirow{2}{*}{252} & $4933.3 \pm 73.4$ & $1951.11 \pm 13.5$ & $48.5 \pm 3.6$ \\
\hline Peanut & 0 & & & $6997.0 \pm 38.1$ & $1680.88 \pm 19.1$ & $62.9 \pm 5.8$ \\
\hline \multicolumn{7}{|l|}{$\mathrm{C}+\mathrm{M}$} \\
\hline Maize & 276 & 126 & 252 & $15573.3 \pm 128.8$ & $5720 \pm 41.6$ & $87.6 \pm 5.2$ \\
\hline \multicolumn{7}{|l|}{$\mathrm{C}+\mathrm{P}+\mathrm{M}$} \\
\hline Maize & 130 & 126 & 252 & $5195.6 \pm 61.2$ & $2044.44 \pm 18.3$ & $47.5 \pm 3.6$ \\
\hline
\end{tabular}

Table 3. Nitrogen fertilization utilization among different treatments.

\begin{tabular}{|c|c|c|c|}
\hline Treatments & Total N (kg/ha) & Fertilizer N (kg/ha) & Fertilizer utilization (\%) \\
\hline \multicolumn{4}{|l|}{$\mathrm{C}$} \\
\hline Crop & $90.3 \pm 7.5$ & $50.67 \pm 6.2$ & 18.36 \\
\hline Soil & $3644.48 \pm 161.5$ & $34.55 \pm 4.8$ & 12.52 \\
\hline Water & $22.93 \pm 8.1$ & - & - \\
\hline Deficit & & & 69.12 \\
\hline Crop & $87.61 \pm 5.2$ & $65.2 \pm 4.5$ & 23.62 \\
\hline Soil & $4804.8 \pm 159.6$ & $63.64 \pm 8.7$ & 23.06 \\
\hline Water & $22.25 \pm 5.2$ & - & - \\
\hline Deficit & & & 53.32 \\
\hline \multicolumn{4}{|l|}{$\mathrm{C}+\mathrm{P}$} \\
\hline Soil & $4058.88 \pm 173.8$ & $39.9 \pm 5.7$ & 30.69 \\
\hline Water & $22.01 \pm 4.5$ & - & - \\
\hline Deficit & & & 44.93 \\
\hline \multicolumn{4}{|l|}{$\mathrm{C}+\mathrm{P}+\mathrm{M}$} \\
\hline Crop & $124.51 \pm 9.0$ & $25.9 \pm 1.9$ & 19.92 \\
\hline Soil & $4878.72 \pm 168.2$ & $61.92 \pm 7.1$ & 47.63 \\
\hline Water & $22.33 \pm 3.2$ & - & - \\
\hline Deficit & & & 32.45 \\
\hline
\end{tabular}




\subsection{Fertilizer N Losses}

Results show that polyculture is one of the most effective ways to reduce fertilizer $\mathrm{N}$ losses. The fertilizer losses in the plots treated by $\mathrm{C}+\mathrm{P}+\mathrm{M}$ and $\mathrm{C}+\mathrm{P}$ were $32.45 \%$ and $44.93 \%$ respectively. However, in the plots treated by $\mathrm{C}$ and $\mathrm{C}+\mathrm{M}$ they were $69.12 \%$ and $53.32 \%$.

Surface straw mulch can reduce the fertilizer $\mathrm{N}$ losses effectively, and in our research it reduced $15.8 \%$ and $12.48 \%$ of fertilize $\mathrm{N}$ losses in the monoculture and polyculture plots respectively. This is because surface straw mulch can reduce soil evaporation and retain soil moisture, which may increase the yield and reduce nutrient losses [33-35].

\section{Conclusions}

According to the results and discussions above, we can confidently draw the following conclusions:

Maize intercrop with peanut is an effective way to reduce fertilizer $\mathrm{N}$ losses, increasing the nitrogen absorption by crops and fertilizer $\mathrm{N}$ retention in the soil profiles (0 - $100 \mathrm{~cm})$; however, it has a lesser effect on NUE.

Compared with un-mulched plots, surface rice straw mulch can reduce nitrogen losses and keep nitrogen in the root zone area $(0-100 \mathrm{~cm})$, however, it should be used in intercropping systems because it may sacrifice the crop dry matter yield in the first season when used in maize monoculture.

\section{Acknowledgements}

This study was supported by Key Project of Nation Spark Program of China (201176GA0009) and National People's Livelihood Science and Technology Plan of China (2011MSB05007).

\section{REFERENCES}

[1] FAO, 2011. http://faostat.fao.org/site/339/default.aspx

[2] D. Tilman, J. Fragione, B. Wolff, C. D’Antonio, A. Dobson, R. Howarth, D. Schindler, W. H. Schelsinger, D. Simerloff and D. Swakhamer, "Forecasting Agriculturally Driven Global Environmental Change,” Science, Vol. 292, No. 5515, 2001, pp. 281-284. doi:10.1126/science.1057544

[3] D. Norse, "Non-Point Pollution from Crop Production: Global, Regional and National Issues,” Pedosphere, Vol. 15, No. 4, 2005, pp. 499-508.

[4] A. Mapiki, G. B. Reddy and B. R. Singh, "Fate of Fertilizer ${ }^{15} \mathrm{~N}$ to a Maize Crop Grown in Northern Zambia," Acta Agriculturae Scandinavica, Section B-Soil \& Plant Science, Vol. 43, No. 4, 1993, pp. 231-237.

[5] H. J. Di and K. C. Cameron, "Nitrate Leaching in Temperate Agro-Ecosystems: Sources, Factors and Mitigating Strategies," Nutrient Cycling in Agroecosystem, Vol. 64, No. 3, 2002, pp. 237-256. doi:10.1023/A:1021471531188
[6] W. W. Zhang, M. J. Shi and Z. H. Huang, "Controlling Non-Point-Source Pollution by Rural Resource Recycling. Nitrogen Runoff in Tai Lake Valley, China, as an Example,” Sustainability Science, Vol. 1, No. 1, 2006, pp. 8389. doi:10.1007/s11625-006-0009-2

[7] X. B. Wang, W. B. Hoogmoed, D. X. Cai, U. D. Perdok and O. Oenema, "Crop Residue, Manure and Fertilizer in Dryland Maize under Reduced Tillage in Northern China: II Nutrient Balances and Soil Fertility," Nutrient Cycling in Agroecosystems, Vol. 79, No. 1, 1996, pp. 17-34. doi:10.1007/s10705-006-9070-6

[8] R. Senaratne, N. D. L. Liyanage and D. S. Ratnasinghe, "Effect of K on Nitrogen Fixation of Intercrop Groundnut and the Competition between Intercrop Groundnut and Maize,” Nutrient Cycling in Agroecosystems, Vol. 34, No. 1, 1993, pp. 9-14. doi:10.1007/BF00749954

[9] A. Aftab, N. Hanley and A. Kampas, "Co-Ordinated Environmental Regulation: Controlling Non-Point Nitrate Pollution while Maintaining River Flows,” Environmental and Resource Economics, Vol. 38, No. 4, 2007, pp. 573-593. doi:10.1007/s10640-007-9090-y

[10] A. Kampas and B. White, “Administrative Costs and Instrument Choice for Stochastic Non-Point Source Pollutants," Environmental and Resource Economics, Vol. 27, No. 2, 2004, pp. 109-133.

[11] A. Maltas, M. Corbeels, E. Scopel, R. Oliver, J.-M. Douzet, F. A. M. da Silva and J. Wery, "Long-Term Effects of Continuous Direct Seeding Mulch-Based Cropping Systems on Soil Nitrogen Supply in the Cerrado Region of Brazil,” Plant and Soil, Vol. 298, No. 1-2, 2007, pp. 161-173. doi:10.1007/s11104-007-9350-1

[12] B. D. Meek, D. L. Carter, D. T. Westermann, J. L. Wright and R. E. Peckenpaugh, "Nitrate Leaching under Furrow Irrigation as Affected by Crop Sequence and Tillage," Soil Science Society of America Journal, Vol. 59, No. 1, 1995, pp. 204-210. doi:10.2136/sssaj1995.03615995005900010031x

[13] J. E. Turpin, J. P. Thompson, S. A. Waring and J. MacKenzie, "Nitrate and Chloride Leaching in Vertosols for Different Tillage and Stubble Practices in FallowGrain Cropping," Australian Journal of Soil Research, Vol. 36, No. 1, 1998, pp. 31-44. doi:10.1071/S97037

[14] A. Inal, A. Gunes, F. Zhang and I. Cakmak, "Peanut/ Maize Intercropping Induced Changes in Rhizosphere and Nutrient Concentrations in Sheoots," Plant Physiology and Biochemistry, Vol. 45, No. 5, 2007, pp. 350-356. doi:10.1016/j.plaphy.2007.03.016

[15] A. C. Franke, G. Laberge, B. D. Oyewole and S. Schulz, "A Comparison between Legume Technologies and Fallow, and Their Effects on Maize and Soil Traits, in Two Distinct Environments of the West African Savannah," Nutrient Cycling in Agroecosystems, Vol. 82, No. 2, 2008, pp. 117-135. doi:10.1007/s10705-008-9174-2

[16] C. G. L. Zaongo, C. W. Wendt, R. J. Lascano and A. S. R. Juo, "Interactions of Water, Mulch and Nitrogen on Sorghum in Niger," Plant and Soil, Vol. 197, No. 1, 1997, pp. 119-126. doi:10.1023/A:1004244109990

[17] T. M. Addiscott, "Fertilizers and Nitrate Leaching,” In: R. E. Hester and R. M. Harrison, Eds., Agricultural Chemi- 
cals and the Environment, Issues in Environmental Science Technology, Vol. 5, 1996, pp. 1-26.

[18] R. J. Haynes and P. H. Williams, "Nutrient Cycling and Soil Fertility in the Grazed Pasture Ecosystem," Advances in Agronomy, Vol. 49, 1993, pp. 119-199. doi:10.1016/S0065-2113(08)60794-4

[19] H. J. Di and K. C. Cameron, "Nitrate Leaching in Temperate Agroecosystems: Sources, Factors and Mitigating Strategies," Nutrient Cycling in Agroecosystems, Vol. 64, No. 3, 2002, pp. 237-256. doi:10.1023/A:1021471531188

[20] Y. N. Song, F. S. Zhang, P. Marschner, F. L. Fan, H. M. Gao, X. G. Bao, J. H. Sun and L. Li, "Effect of Intercropping on Crop Yield and Chemical and Microbiological Properties in Rhizosphere of Wheat, Maize and Faba Bean,” Biology and Fertility of Soils, Vol. 43, No. 5, 2007, pp. 565-574. doi:10.1007/s00374-006-0139-9

[21] C. A. Francis, "Biological Efficiencies in Mixed Multiple Cropping Systems,” Advances in Agronomy, Vol. 42, 1989, pp. 1-42. doi:10.1016/S0065-2113(08)60522-2

[22] L. Li, S. C. Yang, X. L. Li, F. S. Zhang, P. Christie, “Interspecific Complementary and Competitive Interaction between Intercropped Maize and Faba Bean,” Plant and Soil, Vol. 212, No. 2, 1999, pp. 105-114. doi:10.1023/A:1004656205144

[23] M. Karpenstein-Machan and R. Stuelpnagel, "Biomass Yield and Nitrogen Fixation of Legumes Monocropped and Intercropped with Rye and Rotation Effects on a Subsequent Maize Crop,” Plant and Soil, Vol. 218, No. 1-2, 2000, pp. 215-232. doi:10.1023/A:1014932004926

[24] R. C. Martin, H. D. Voldeng and D. L. Smith, "Nitrogen Transfer from Nodulating Soybean to Maize or to NonNodulating Soybean in Intercrop: The ${ }^{15} \mathrm{~N}$ Dilution Methods,” Plant and Soil, Vol. 132, No. 1, 1991, pp. 53-63. doi:10.1007/BF00011012

[25] E. S. Jensen, "Barley Uptake of N Deposited in the Rhizosphere of Associated Field Pea," Soil Biology and Biochemistry, Vol. 28, No. 2, 1996, pp. 159-168.

[26] M. Liedgens, E. Frossard and W. Richner, "Interaction of Maize and Italian Rygrass in a Living Mulch System: (2) Nitrogen and Water Dynamics," Plant and Soil, Vol. 259, No. 1-2, 2004, pp. 243-258. doi:10.1023/B:PLSO.0000020965.94974.21
[27] R. W. Willey, "Intercropping-Its Importance and Research Needs. Part 1. Competition and Yield Advantages,” Field Crop Abstracts, Vol. 32, 1979, pp. 1-10.

[28] R. W. Willey and M. R. Rao, "A Competitive Ratio for Quantifying Competition between Inter-Crops,” Experimental Agriculture, Vol. 16, No. 2, 1980, pp. 117-125. doi:10.1017/S0014479700010802

[29] R. W. Willey, M. Natarajan, M. S. Reddy, M. R. Rao, P. T. C. Nambiar, J. Kannaiyan and V. S. Bhatnagar, "Intercropping Studies with Annual Crops,” In: J. Nugent and M. O’Connor, Eds., Better Crops for Food, Pitman Books, London, 1983, pp. 83-100.

[30] S. T. Ikerra1, J. A. Maghembe, P. C. Smithson and R. J. Buresh, "Soil Nitrogen Dynamics and Relationships with Maize Yields in a Gliricidia-Maize Intercrop in Malawi,” Plant and Soil, Vol. 211, No. 2, 1999, pp. 155-164. doi:10.1023/A:1004636501488

[31] P. K. Ghosh, M. Mohanty, K. K. Bandyopadhyay, D. K. Painuli and A. K. Misra, "Growth, Competition, Yields Advantage and Economics in Soybean/Pigeonpea Intercropping System in Semi-Arid Tropics of India: II. Effect of Nutrient Management,” Field Crops Research, Vol. 96, No. 1, 2006, pp. 90-97. doi:10.1016/j.fcr.2005.05.010

[32] A. Siczek and J. Lipiec, "Soybean Nodulation and Nitrogen Fixation in Response to Soil Compaction and Surface Straw Mulching," Soil and Tillage Research, Vol. 114, No. 1, 2011, pp. 50-56. doi:10.1016/j.still.2011.04.001

[33] B. S. Sandhu, B. Singh, B. Singh and K. L. Khera, "Maize Response to Intermittent Submergence, Straw Mulching and Supplemental N-Fertilization in Subtropical Region,” Plant and Soil, Vol. 96, No. 1, 1986, pp. 45-46. doi:10.1007/BF02374994

[34] J. A. Tolk, T. A. Howell and S. R. Evett, "Effect of Mulch, Irrigation, and Soil Type on Water Use and Yield of Maize," Soil and Tillage Research, Vol. 50, No. 2, 1999, pp. 137-147. doi:10.1016/S0167-1987(99)00011-2

[35] Q. Q. Li, Y. H. Chen, M. Y. Liu, X. B. Zhou, S. L. Yu and B. D. Dong, "Effects of Irrigation and Straw Mulching on Microclimate Characteristics and Water Use Effeciency of Winter Wheat in North China,” Plant Production Science, Vol. 11, No. 2, 2008, pp. 161-170. doi:10.1626/pps.11.161 